Pak. j. sci. ind. res. Ser. A: phys. sci. 2017 60(3) 128-133

\title{
Efficiency for Sorption Behaviour of Polymeric Resins of (2-hydroxybenzaldehyde) with Aliphatic and Aromatic Diamines Towards Different Metal Ions
}

\author{
Ambreen Shah ${ }^{a *}$, Asif Ali Shah ${ }^{\mathrm{b}}$ and Sobia Shafaq Shah \\ ${ }^{a}$ M.A. Kazi Institute of Chemistry, University of Sindh, Jamshoro, Sindh, Pakistan \\ ${ }^{b}$ Mehran University Institute of Science \& Technology Development, Jamshoro, Sindh, Pakistan \\ ${ }^{c}$ Institute of Bussiness Administration, University of Sindh, Jamshoro, Sindh, Pakistan \\ (received April 29, 2017; revised August 23, 2017; accepted August 28, 2017)
}

\begin{abstract}
Aliphatic and aromatic polymeric resins of (2-hydroxybenzaldehyde) with 1,2-propylenediamine and 1,4-phenylenediamine were synthesised and characterised employing elemental and thermal analysis, FT-IR and UV-visible spectroscopy. The metal uptake behaviour of synthesised polymers (PMBHBPn, $\mathrm{PMBHBPh}$ ) towards different metal ions were investigated and optimised by variety of conditions. The sorption data of these metal ions were followed Langmuir, Freundlich, and Dubinin-Radushkevich (D-R) isotherms. The Freundlich parameters were computed at $1 / n=0.26 \pm 0.02,0.309 \pm 0.02,0.35 \pm$ $0.05,0.368 \pm 0.04$ and $0.23 \pm 0.01, A=3.9 \pm 0.03,4.31 \pm 0.02,4.683 \pm 0.01,5.43 \pm 0.03$, and $2.81 \pm 0.05$ $\mathrm{mmol} / \mathrm{g}$ for $\mathrm{Cu}(\mathrm{II}), \mathrm{Co}(\mathrm{II}), \mathrm{Ni}(\mathrm{II}), \mathrm{Fe}(\mathrm{III})$ and $\mathrm{Cd}(\mathrm{II})$ ions, respectively. The variation of sorption with temperature gives thermodynamic quantity $(\Delta \mathrm{H})$ in the range of $(\mathrm{AH}=36.33-52.14 \mathrm{KJ} / \mathrm{mol})$ for (PMBHBPn) and (39.21-56.29 KJ/mol) for $(\mathrm{PMBHBPh})$. The sorption procedure could preconcentrate metal ions, and it can be determined by atomic absorption spectrophotometer.
\end{abstract}

Keywords: polymeric resin, sorption, isotherms, kinetics, thermodynamics

\section{Introduction}

The metals have high density as compared to water (Bradl, 2002). The bulkiness and toxicity are interconnected with heavy metals including metalloids at low level of exposure (He et al., 2005). In recent times, there are rising ecological and global public health issues related to environmental toxicity by heavy metals. Similarly, human exposures are also rising dramatically as a result of their numerous uses in industrial, agricultural, domestic and technological activities (Harvey and Mcardle, 2008). However, the sources of heavy metals in the surroundings included geogenic, industrial, agricultural, pharmaceutical and domestic effluents and atmospheric sources are affecting all the living species (Wang and Shi, 2001). Different industrial processes are the main source of environmental pollutions (Beyersmann and Hartmig, 2008) and (Atsdr, 2002). Hence, heavy metals are also known as toxic metals even at lower concentrations (ppb range to less than $10 \mathrm{ppm}$ ) in different environmental samples.

Copper is an essential element for all living organisms because it is a key constituent for proper growth and

*Author for correspondence;

E-mail: ambreen.shah@usindh.edu.pk health. In humans, copper is mostly existing in the liver, muscle, and bones (WHO, 1996). The mature body contains 1.4-2.1 mg of copper per kg of body weight. The precision quantities of nickel and cobalt have also been revealed to be essential for healthy life, such as level of nickel should not be exceeded to $5 \mathrm{ppm}$ in drinking water (Sari et al., 2007; Xie et al., 2005). Cobalt is one of the essential elements for life but chronic cobalt intake has caused serious health problems (Kocaoba, 2008; Akl et al., 2004). The estimated value for soluble cobalt salts is $150-500 \mathrm{mg} / \mathrm{kg}$. Iron is an essential mineral found in every cell of the body because it is needed to make hemoglobin, a part of blood cells (Blain and Traguer, 1995).

Chelating resins are designed as useful sorbent resins for determining concentration of metal ions from different environmental samples (Bortoleto et al., 2004; Saracoglu and Elci, 2002). Different polymeric resins indicated the equilibrium of adsorption method and also compared with different adsorption isotherm equations like Sips, Langmuir, Freundlich, and linear adsorption isotherms (Fafy et al., 2010; Xiaojun et al., 2010). Ortho hydroxyl derivatives also indicated positive ability to form the metal complexes with Schiff base polymers (Samal et al., 1997; 1996). This research describes the 
synthesis of polymeric Schiff base of 2-hydroxy benzaldehyde with aliphatic diamine (1,2-propylenediamine) and aromatic diamine (1,4-phenylenediamine) by polycondensation reaction and utilized as adsorbent (resins) for $\mathrm{Cu}(\mathrm{II}), \mathrm{Co}(\mathrm{II}), \mathrm{Ni}(\mathrm{II}), \mathrm{Fe}(\mathrm{III})$ and $\mathrm{Cd}(\mathrm{II})$ ions. The preconcentration was followed in this sorption method and the concentrations were determined by atomic absorption spectrophotometer.

\section{Materials and Methods}

Reagents and materials. All chemicals were of analytical grade. 2-hydroxybenzaldehyde, 1,2-propylenediamine, 1,4-phenylenediamine, formaldehyde, organic solvents (ethanol, methanol, $n$-hexane), $\mathrm{HCl}, \mathrm{KCl}$, acetic acid, sodium acetate, ammonia and $\mathrm{NH}_{4} \mathrm{Cl}$ solutions were required and purchased from Merck/Germany.

Instruments. FT-IR spectrophotometer and thermal analyzer were the two main instruments used in this study. FTIR-spectrum was recorded on Nicolet Avatar 330 FT-IR with total attenuated reflectance (ATR) accessory. Spectrophotometric studies were carried out in tetrahydrofuran (THF) using double beam Hitachi 220 spectrophotometer (Hitachi (Pvt) Tokyo, Japan). Thermogravimetry (TG) was recorded on Pyris Diamond TG/DTA (Perkin Elmer, Japan) from room temperature to $550{ }^{\circ} \mathrm{C}$ against $\alpha$-alumina as reference.

Preparation of resin. The Schiff base polymers of 2hydroxybenzaldehyde with aliphatic and aromatic diamines were prepared by reported procedure (Samal, 1997) with some modifications.

Schiff base (1.2 g) of (2-hydroxybenzaldehyde) was dissolved in $20 \mathrm{~mL}$ distilled water and added about 10-12 drops of $2 \mathrm{M} \mathrm{NaOH}$. The mixture was slightly heated at $50{ }^{\circ} \mathrm{C}$ for $10 \mathrm{~min}$, during that time formaldehyde $(37 \% \mathrm{v} / \mathrm{v}, 2.4 \mathrm{~mL})$ also added with continuous stirring on hot plate. The mixture was refluxed for $2.5 \mathrm{~h}$ at $120{ }^{\circ} \mathrm{C}$. After refluxing, poured the mixture, filtered the precipitates and washed with hot water. Melting point of resin was higher than $300^{\circ} \mathrm{C}$. Structure diagram of polymers is shown in Fig. 1(a-b). Elemental analysis of polymeric resins is as follows:

1. Poly (5,5'-methylene bis(2-hydroxy benzaldehyde)1,2-propylenediimine) $\left(\mathrm{C}_{18} \mathrm{H}_{21} \mathrm{~N}_{2} \mathrm{O}_{2}\right) \mathrm{n}$, Calculated C, $76.83 \%$; H, $4.87 \%$; N, $8.53 \%$. Found C, $76.66 \%$; H, $4.89 \%$; N, 8.51\%.

2. Poly (5,5'-methylene bis(2-hydroxy benzaldehyde)1,4-phenylenediimine) Elemental
$\left(\mathrm{C}_{21} \mathrm{H}_{19} \mathrm{~N}_{2} \mathrm{O}_{2}\right)$ n, calculated: $\mathrm{C}, 76.83 \% ; \mathrm{H}, 4.87$

$\%$; N, $8.53 \%$. Found: C, $76.66 \%$; H, $4.89 \%$; $\mathrm{N}, 8.51$

Sorption process. Preparation of solution by batch method. Polymers (PMBHBPn \& PMBHBPh) (0.1 g) were treated with aqueous solution of $0.05 \mathrm{M} \mathrm{Cu}$ (II) $\mathrm{Co}(\mathrm{II}), \mathrm{Ni}(\mathrm{II}), \mathrm{Fe}(\mathrm{III})$ and $\mathrm{Cd}(\mathrm{II})$ metal ions of known concentration $(10 \mathrm{~mL}, 2000 \mu \mathrm{g} / \mathrm{mL})$. The $\mathrm{pH}$ of solution was maintained with buffer. The concentrations of unknown solutions were determined by atomic absorption spectrophotometerically. After knowing the concentration of solutions, maximum percentage of sorption and the distribution co-efficient $(\mathrm{Kd})$ were calculated from following equations.

$\%$ Sorption $=\mathrm{Ci}-\mathrm{Cf} / \mathrm{Ci} \times 100$.

$\mathrm{Ci}=$ Initial concentration of metal ions in solution $(\mathrm{mg} / \mathrm{L})$

$\mathrm{Cf}=$ Final concentration of metal ions in solution $(\mathrm{mg} / \mathrm{L})$.

$$
\begin{aligned}
\mathrm{Kd}= & \frac{\text { mmol metal ion in resin }}{\text { mmol metal ion in the solution }} \times \ldots \ldots . . . \\
& \frac{\text { volume of solution }(\mathrm{mL})}{\text { weight of resin }(\mathrm{g})}
\end{aligned}
$$

All thermodynamic parameters like $\Delta \mathrm{H}, \Delta \mathrm{G}$ and $\Delta \mathrm{S}$ were obtained from the following relationships:

$$
\log \mathrm{K}_{\mathrm{c}}=\frac{-\Delta \mathrm{H} \mathrm{RT}}{2.303}+\frac{\Delta \mathrm{R}}{2.303}
$$$$
\Delta \mathrm{G}=-\mathrm{RT} \ln \mathrm{K}_{\mathrm{c}}
$$

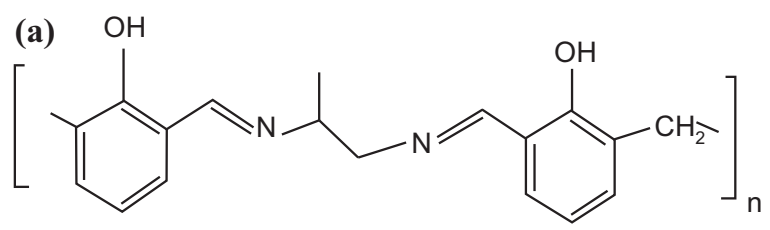

(b)

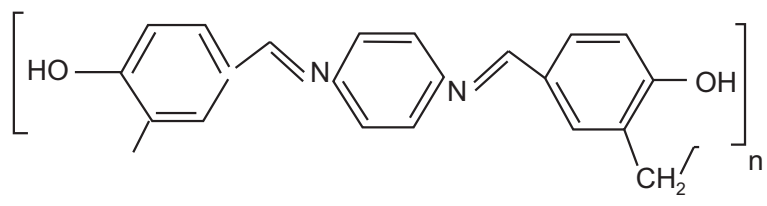

Fig. 1(a-b). Structural diagram of Ploy[5,5'-methylenebis (2-hydroxybenzaldehyde)1,2propylenediimine]. 


\section{Results and Discussion}

Characterisation of resins. The FTIR spectrum of polymers (PMBHBPn and PMBHBPh) showed all main characterisation peaks such as $\mathrm{C}=\mathrm{N}$ stretching vibration at 1636.62 and $1648.34 \mathrm{~cm}^{-1}$, the main $\mathrm{O}-\mathrm{H}$ band appeared at 1258 and $1265 \mathrm{~cm}^{-1}$ and $\mathrm{C}=\mathrm{C}$ bands at $1533-1618 \mathrm{~cm}^{-1}$, respectively in Fig. 2(a-b).

The data of ultra violet - visible spectrum of polymeric resins (PMBHBPn) and (PMBHBPh) show three absorption bands at $248-253 \mathrm{~nm}(1 \% \varepsilon=463-457 \mathrm{~L}$ $\mathrm{g} / \mathrm{cm}), 282-296 \mathrm{~nm}(1 \% \varepsilon=275.4-266.3 \mathrm{~L} / \mathrm{g} / \mathrm{cm})$, and $342-346 \mathrm{~nm}(1 \% \varepsilon=205.8-207.5 \mathrm{~L} / \mathrm{g} / \mathrm{cm})$, respectively (Fig. 3a-b).

Thermal stability of polymeric resins was observed on thermogravimetry thermal analyzer and it gives two mass loss steps from room temperature to $550{ }^{\circ} \mathrm{C}$, (Fig. 4). This suggested that the maximum mass loss is $76 \%$ at about $422{ }^{\circ} \mathrm{C}$ which referred the rigidity of polymeric resin.
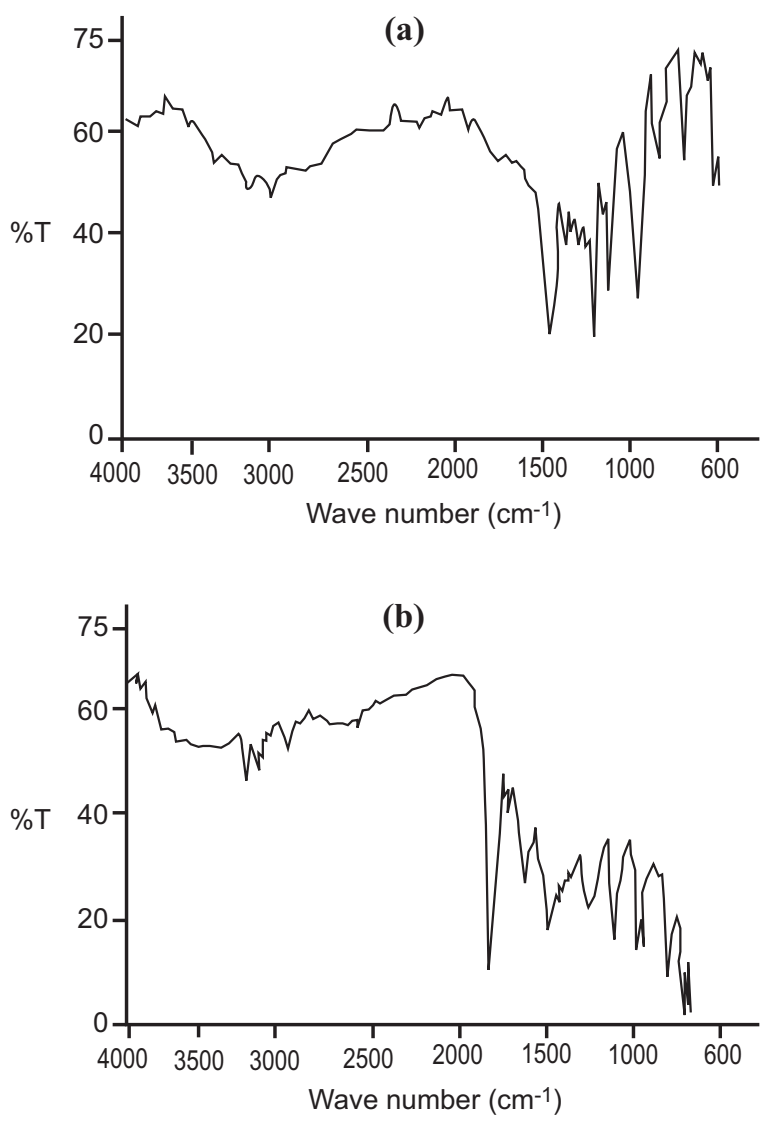

Fig. 2(a-b). FTIR spectra of (a) (PMBHBPn) (b) (PMBHBPh).
Sorption studies using batch method. Optimized parameters. The effect of $\mathrm{pH}$ on both polymeric resins (PMBHBPn \& PMBHBPh) was observed by using different buffers with $\mathrm{pH} 2-10$ to obtain maximum $\%$ sorption of each metal ions at appropriate $\mathrm{pH}$. The sorption $\%$ became high with rising $\mathrm{pH}$ of solution and
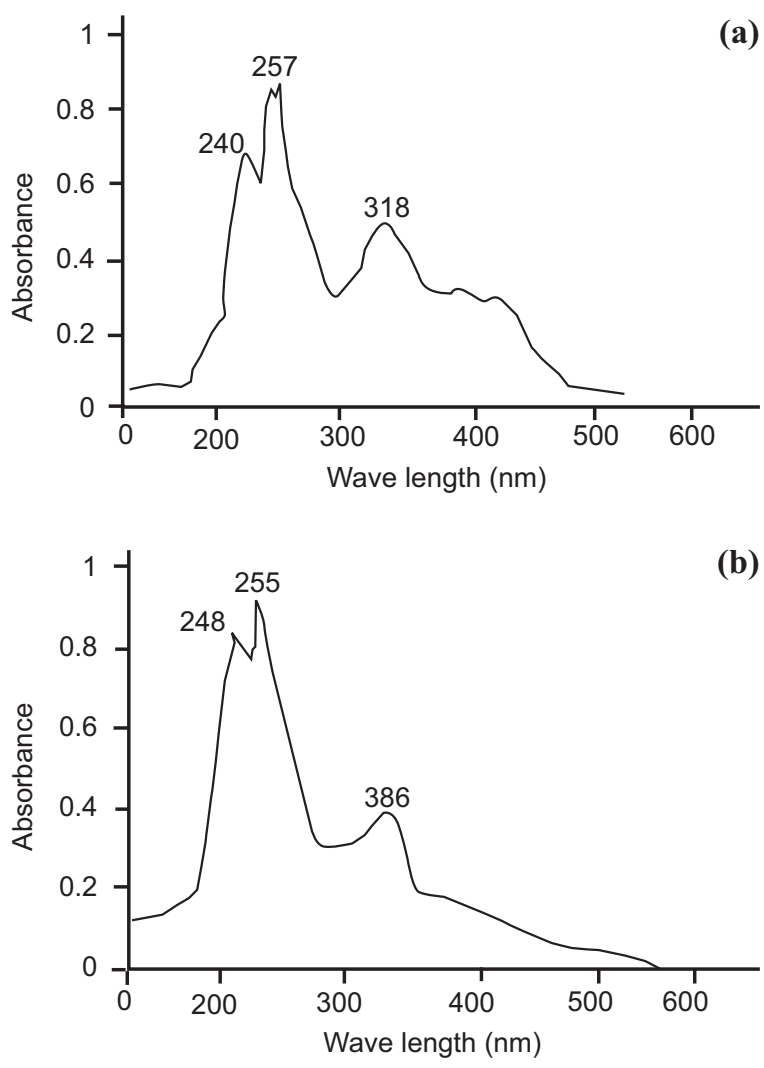

Fig. 3(a-b). UV-visible spectra of (a) (PMBHBPn) (b) (PMBHBPh).

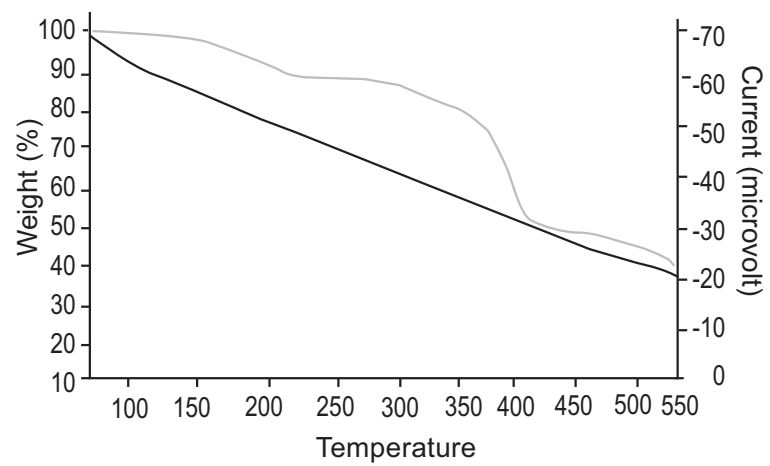

Fig. 4. TG thermograph of Poly[5,5'-methylenebis (2hydroxybenzaldehyde)1,2-propylenediimine]. 
attained a maximum value at $\mathrm{pH} 4$ for $\mathrm{Fe}(\mathrm{III}), \mathrm{pH} 6.2$ for $\mathrm{Cu}$ (II) and $\mathrm{Cd}(\mathrm{II})$ but $\mathrm{pH} 8$ for $\mathrm{Co}(\mathrm{II})$ and $\mathrm{Ni}(\mathrm{II})$ metal ions. The metal uptake activities of resins improved the alkalinity of $\mathrm{C}=\mathrm{N}$ at higher $\mathrm{pH}$ with maximum $\%$ sorption. The results are shown in Fig. 5(a-b).
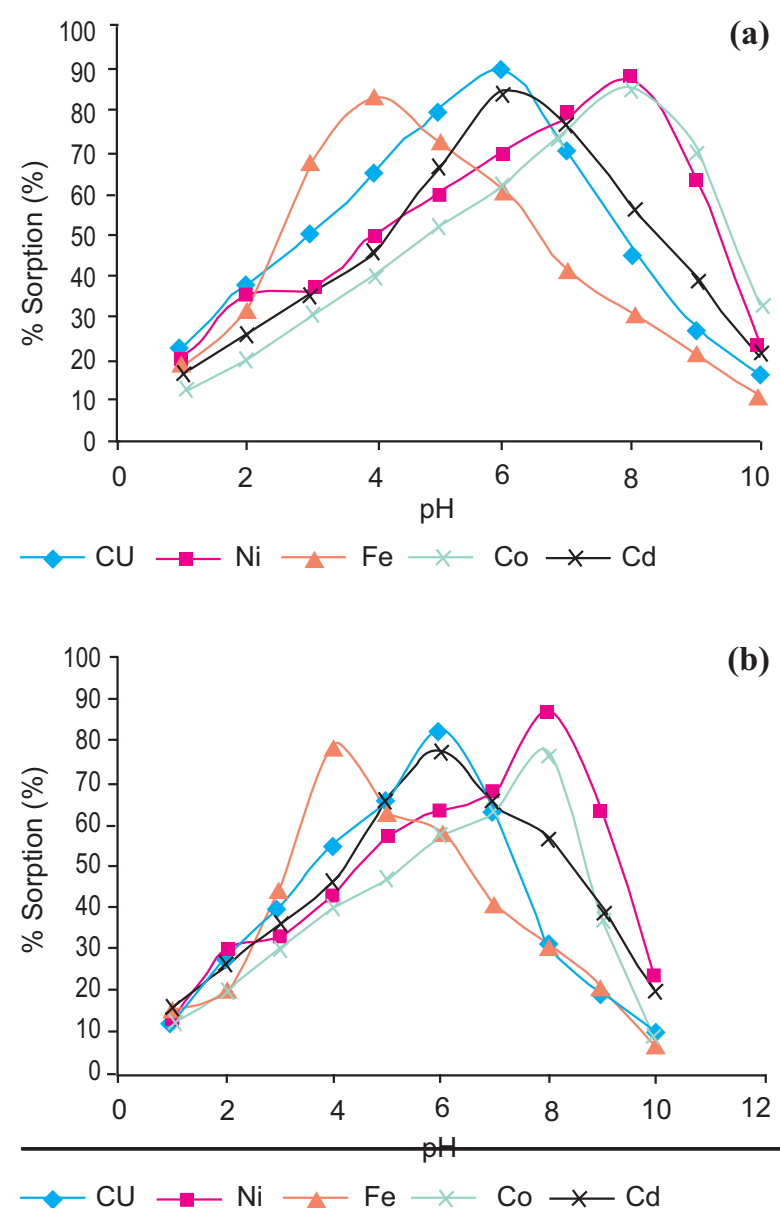

Fig. 5(a-b). Effect of pH on resin (PMBHBPn) for \% sorption of $\mathrm{Cu}(\mathrm{II}), \mathrm{Co}(\mathrm{II}), \mathrm{Ni}(\mathrm{II}), \mathrm{Fe}(\mathrm{III})$ and $\mathrm{Cd}(\mathrm{II})$ using batch method.
Sorption isotherms. The efficiency of $\mathrm{Cu}(\mathrm{II}), \mathrm{Ni}(\mathrm{II})$, $\mathrm{Fe}(\mathrm{III}), \mathrm{Co}(\mathrm{II})$ and $\mathrm{Cd}(\mathrm{II})$ metal ions on both polymeric resins was determined by the help of different isothermal equations, which are shown as below:

Freundlich equation:

$(\log \mathrm{Cads}=\log \mathrm{A}+(1 / \mathrm{n}) \log \mathrm{Ce}$.

Langmuir equation:

$(\mathrm{Ce} / \mathrm{Cads})=(1 / \mathrm{Qb})+(\mathrm{Ce} / \mathrm{Q})$

Dubinin -Radushkevich equation:

$\left(\ln\right.$ Cads $\left.=\ln \mathrm{Xm}-\beta \varepsilon^{2}\right)$

where:

$\varepsilon=$ calculated by RT $\ln (1+(1 / \mathrm{Ce}))$ equation, $\mathrm{Ce}$ is the amount of metal ions in the liquid phase at equilibrium and Cads is the amount of metal ions adsorbed/mass of adsorbent. The Freundlich (A) (n), Langmuir (Q) (b) and Dubinin -Radushkevich (Xm) $(\beta)$ were constants listed in Table 1 which concluded that \% sorption decrease at low temperature.

Thermodynamic of sorption. The results of enthalpy of activation energy $(\Delta \mathrm{H})$, Gibb's free energy $(\Delta \mathrm{G})$ and entropy $(\Delta S)$ were obtained from the plot of slope and intercept of enthalpy of activation energy for all above metal ions, and given in Table 2. The parameters enthalpy of activation energy and free energy obtained negative results that indicated exothermic reaction and spontaneous nature of the sorption of metal ions.

Stability of sorbent (Desorption). The stability of polymeric sorbents was examined via several loading of resin as well as its \% yield of resin recovery. This polymeric resin was checked about 6 times at optimised conditions, indicated high desorption rate and showed that the resins (PMBHBPn \& PMBHBPh) were feasible for sorption.

Table 1. Sorption parameters of $\mathrm{Cu}(\mathrm{II}), \mathrm{Co}(\mathrm{II}), \mathrm{Ni}(\mathrm{II}), \mathrm{Fe}(\mathrm{III})$ and $\mathrm{Cd}(\mathrm{II})$ ions $\left(5.6 \times 10^{-7}\right.$ to $\left.4.7 \times 10^{-4} \mathrm{M}\right)$ on synthesized resin (PMBHBPn) $(100 \mathrm{mg})$ at $30^{\circ} \mathrm{C}$

\begin{tabular}{|c|c|c|c|c|c|c|c|c|c|}
\hline \multirow[t]{2}{*}{ Metal } & \multicolumn{3}{|c|}{ Freundlich } & \multicolumn{3}{|c|}{ Langmuir } & \multicolumn{3}{|c|}{ D-R } \\
\hline & $\begin{array}{l}\mathrm{A} \\
(\mathrm{mmol} / \mathrm{g})\end{array}$ & $1 / \mathrm{n}$ & $\mathrm{R}$ & $\begin{array}{l}\mathrm{Q} \\
(\mathrm{mmol} / \mathrm{g})\end{array}$ & $\begin{array}{l}\text { B } \\
(\mathrm{I} / \mathrm{mol})\end{array}$ & $\mathrm{R}$ & $\begin{array}{l}\mathrm{Xm} \\
(\mathrm{mmol} / \mathrm{g})\end{array}$ & $\begin{array}{l}\mathrm{E} \\
(\mathrm{Kj} / \mathrm{mol})\end{array}$ & $\mathrm{R}$ \\
\hline $\mathrm{Fe}(\mathrm{III})$ & 5.43 & 0.368 & 0.996 & 0.05 & $2.7 \times 10^{2}$ & 0.98 & 0.78 & 12.8 & 0.95 \\
\hline $\mathrm{Ni}(\mathrm{II})$ & 4.683 & 0.35 & 0.991 & 0.04 & $1.6 \times 10^{3}$ & 0.99 & 0.69 & 12.4 & 0.97 \\
\hline $\mathrm{Co}(\mathrm{II})$ & 4.31 & 0.309 & 0.979 & 0.05 & $3.5 \times 10^{3}$ & 0.99 & 0.62 & 10.3 & 0.99 \\
\hline $\mathrm{Cu}(\mathrm{II})$ & 3.9 & 0.26 & 0.994 & 0.07 & $4.2 \times 10^{4}$ & 0.97 & 0.37 & 9.7 & 0.99 \\
\hline $\mathrm{Cd}(\mathrm{II})$ & 2.81 & 0.23 & 0.998 & 0.08 & $5.4 \times 10^{4}$ & 0.98 & 0.31 & 9.02 & 0.99 \\
\hline
\end{tabular}


Table 2. Thermodynamic parameters of $\mathrm{Cu}(\mathrm{II}), \mathrm{Co}$ (II), $\mathrm{Ni}(\mathrm{II}), \mathrm{Fe}(\mathrm{III})$ and $\mathrm{Cd}(\mathrm{II})$ metal ions on polymeric resin (PMBHBPn) $303 \mathrm{~K}$

\begin{tabular}{lllll}
\hline \hline Metals & $\Delta \mathrm{H}(\mathrm{kJ} / \mathrm{mol})$ & $\Delta \mathrm{G}(\mathrm{kJ} / \mathrm{mol})$ & $\Delta \mathrm{S}(\mathrm{kJ} / \mathrm{mol})$ & $\mathrm{RSD}$ \\
\hline $\mathrm{Fe}(\mathrm{III})$ & $-47.27 \pm 0.15$ & $-1.48 \pm 0.07$ & $-0.103 \pm 0.072$ & 0.996 \\
$\mathrm{Ni}(\mathrm{II})$ & $-45.21 \pm 0.43$ & $-2.14 \pm 0.05$ & $-0.114 \pm 0.009$ & 0.938 \\
$\mathrm{Co}(\mathrm{II})$ & $-41.28 \pm 0.37$ & $-2.25 \pm 0.05$ & $-0.123 \pm 0.021$ & 0.991 \\
$\mathrm{Cu}(\mathrm{II})$ & $-52.14 \pm 0.08$ & $-1.6 \pm 0.02$ & $-0.113 \pm 0.043$ & 0.998 \\
$\mathrm{Cd}(\mathrm{II})$ & $-36.33 \pm 0.31$ & $-4.2 \pm 0.03$ & $-0.102 \pm 0.001$ & 0.929 \\
\hline \hline
\end{tabular}

Interference study. The sorption of all metal ions may be affected due to the presence of different cations and anions which may form variety of metal complexes. Some cations and anions were helpful to examine their interference for both resins (PMBHPn \& PMBHBPh) with metal ions under the optimum conditions.

Analytical performance. For the validity of method, the application work was carried out for both resins (PMBHBPn \& PMBHBPh), the concentrations of $\mathrm{Cu}$ (II) and $\mathrm{Ni}$ (II) metal ions were determined from different water samples. The results indicated that the proposed method is reliable and valid for the sorption of other environmental samples.

\section{Conclusion}

Polymeric resin has great capacity to adsorbent and removes different metal ions with different characteristics. This work demonstrated that the synthesized polymer resins (2-hydroxybenzaldehyde with aliphatic and aromatic diamines) can successfully remove various metal ions from their dilute solutions. It was also concluded that the percentage of adsorption is $\mathrm{Cd}$ (II) $>\mathrm{Co}(\mathrm{II})>\mathrm{Fe}(\mathrm{III})>\mathrm{Ni}(\mathrm{II})>\mathrm{Cu}(\mathrm{II})$. The maximum $\%$ sorptions of metal ions were decreased at low temperature. All thermodynamic parameters were indicated spontaneous nature and exothermic reaction. Therefore, the rigidity of polymeric resins (PMBHBPn \& $\mathrm{PMBHBPh}$ ) was positively achieved and had least matrix interference with other common ions.

\section{References}

Akl, M.A.A., Kenawy, I.M.M., Lasheen, R.R. 2004. Originally modified silica gel and flame atomic absorption spectrometry: employment for separation and preconcentration of nine trace heavy metals for their determination in natural aqueous systems. Microchemical Journal, 78: 143-156.
ATSDR, 2002. Toxicological Profile for Copper. Agency for Toxic Substances and Disease Registry, Atlanta, GA, USA.

Beyersmann, D., Hartwig, A. 2008. Carcinogenic metal compounds, recent insight into molecular and cellular mechanisms. Archives of Toxicology, 82: 493-512.

Blain, S., Treguer, P. 1995. Determination of iron(II) and iron(III) in seawater at the nano level with selective on-line preconcentration and spectrophotometric determination. Anatytica Chimica Acta, 308: 425-432.

Bortoleto, G., Macarovscha, G.T., Cadore, S. 2004. Determination of cadmium by flame atomic absorption on silica gel modified with cupferron. Journal of Brazil Chemical Society, 15: 313.

Bradl, H. 2002. Heavy Metals in the Environment, Origin, Interaction and Remediation, vol. 6, $1^{\text {st }}$ edition, pp. 306, Academic Press, London, UK.

Fa, F.Y., Zhi, S.H., Xiao, Y.Z., Hong, Y.G. 2010. Thiacalix[4]amido-based Netty Polymers: Novel sorbents for heavy metal cations and derivatives of aniline. Iranian Polymer Journal, 19: 309-318.

Harvey, L.J., McArdle, H.J. 2008. Biomarkers of copper status, a brief update. British Journal of Nutrition, 99: S10-S13.

He, Z.L., Yang, X.E., Stoffella, P.J. 2005. Trace elements in agro ecosystems and impacts on the environment. Journal of Trace Element Medical Biology, 19: 125-140.

Kocaoba, S. 2008. Adsorption of $\mathrm{Ni}$ (II) and $\mathrm{Co}$ (II) ions and application of surface complex formation model to ion exchange equilibria. Environment of Engineering Sciences, 25: 697-702.

Samal, S., Das, R.R., Sahoo, D., Acharya, S., Panda, R.L., Rout, R.C. 1997. Chelating resins, synthesis, characterization and capacity studies of formaldehyde- condensed phenolic schiff bases derived from 4,4'-diaminodiphenylmethane, witho-hydroxyacetophenone. Polymer International, 44: 41-48.

Samal, S., Das, R.R., Sahoo, D., Acharya, S., Panda, R.S., Rout, R.C. 1996. Chelating resins, synthesis, characterization and capacity studies of formaldehyde- condensed phenolic schiff bases derived from 1,2- diamines with hydroxy benzaldehyde. Journal of Applied Polymer Science, 62: 14371444.

Saracoglu, S., Elci, L. 2002. Column solid-phase extraction with Chromosorb -102 resin and determination of trace elements in water and sediment 
samples by flame atomic absorption spectrometry. Analytica Chimica Acta, 452: 77.

Sari, A., Tuzen, M., Citak, D., Soylak, M. 2007. Adsorption characteristics of $\mathrm{Cu}$ (II) and $\mathrm{Pb}$ (II) onto expanded perlitre from aqueous solution. Hazardous Material, 148: 387-394.

Wang, S., Shi, X. 2001. Molecular mechanisms of metal toxicity and carcinogenesis. Molecular Cell Biochemistry, 222: 3-9.

WHO, 1996. Trace Elements in Human Nutrition and Health, 361 pp., World Health Organization, Geneva,
Switzerland.

Xiaojun, H.U., Yushuang, L.I., Wang, Y., Huiying, L.I., Xiao, L.I.U., Zhang, P.I.N. 2010. Adsorption kinetics, thermodynamics and isotherm of thiacalix[4]areneloaded resin to heavy metal ions. Desalination, 259: 76-83.

Xie, Z.H., Zie, F.Z., Guo, L.Q., Lin, X.C., Chen, G.N. 2005. Thioacetamide chemically immobilized on silica gel as a solid extractant for the extraction and preconcentration of $\mathrm{Cu}(\mathrm{II})$ and $\mathrm{Cd}(\mathrm{II})$. Journal of Separation Science, 470: 462-470. 